\title{
G-2548A Leptin Promoter and Q223R Leptin Receptor Polymorphisms in Obese Mexican Subjects
}

\author{
${ }^{1,2}$ Carrillo-Vazquez Jonathan P., \\ ${ }^{2}$ Lopez-Alcantar Jeronimo, ${ }^{1,2}$ Chimal-Vega Brenda, \\ ${ }_{1,2}$ Benitez-Cardoza Claudia, ${ }^{1,2}$ Zamorano-Carrillo Absalom, \\ ${ }^{1,2}$ Reyes-Lopez Cesar, ${ }^{3}$ Lopez-Camarillo Cesar and ${ }^{1,2}$ A. Marchat Laurence \\ ${ }^{1}$ NPI Biotechnology Program, National School of Medicine, \\ Homeopathy of the National Polytechnic Institute, Guillermo Massieu Helguera 239, 07320, Mexico \\ ${ }^{2}$ Institutional Program of Molecular Biomedicine, National School of Medicine, \\ Homeopathy of the National Polytechnic Institute, Guillermo Massieu Helguera 239, 07320, Mexico \\ ${ }^{3}$ Genomics Sciences Program, Oncogenomics and Cancer Proteomics Laboratory, \\ Autonomous University of Mexico City, Avenue San Lorenzo 290, 03100, Mexico
}

Received 2012-04-14, Revised 2013-01-04; Accepted 2013-02-12

\begin{abstract}
Leptin interaction with its receptor in the hypothalamus stimulates a specific signaling cascade that results in the synthesis of anorexigenic and orexigenic peptides in order to regulate food intake and energy expenditure. Many polymorphisms in leptin (lep) and leptin receptor (lepr) genes have been associated with body weight. In particular, G-2548A in the lep promoter and Q223R in lepr variants have been associated with obesity in several populations, although no linkage has been evidenced in others. Here, we examined the genetic associations of these polymorphisms with Body Mass Index (BMI) and serum leptin levels in adult Mexican people. A set of 160 subjects was recruited at the Acupuncture Clinic of the National School of Medicine and Homeopathy of the National Polytechnic Institute (Mexico) and classified according to BMI, gender and age. Blood samples were obtained to extract genomic DNA and determine genetic variants by PCR-RFLP. Leptin was quantified by ELISA assays. Analysis of association and determination of Odd Ratio (OR) were performed using SPSS software. G-2548A in lep gene promoter and Q223R in lepr gene polymorphisms were not found associated with BMI in the whole study population. However, GG genotype in lep gene promoter was related to an increased leptin concentration $(\mathrm{p} \leq 0.05)$ and suggested as a protective factor for obesity in Mexican women. Leptin levels were higher in postmenopausal women, confirming the link between the hormonal system and body weight control. In contrast, no association was found between lepr gene polymorphism and serum leptin level. Our results suggest a possible association between G-2548A polymorphism in lep gene promoter, BMI and leptin levels in Mexican women. Further analysis of a larger population is required to confirm the biological relevance of this polymorphism for obesity in the Mexican population.
\end{abstract}

Keywords: Lep and Lepr Polymorphisms, Leptin, Mexican Population, Obesity

\section{INTRODUCTION}

Obesity is a metabolic disorder that results from deregulation between food intake and energy expenditure, leading to fat mass accumulation and body weight increase. In the last decade, obesity has become a major public health problem affecting more than 250 million people worldwide. Particularly, overweight and obesity in the Mexican population is one of the highest worldwide $(70 \%)$ (http://www.who.int/en/). Notably, obesity has been identified as a risk factor for degenerative diseases, such as diabetes, hypertension and Corresponding Author: A. Marchat Laurence, NPI Biotechnology Program, National School of Medicine, Homeopathy of the National Polytechnic Institute, Guillermo Massieu Helguera 239, 07320, Mexico Tel: (52) 55-5729-6300, ext. 55543 
coronary heart disease, which represent the main causes of death in Mexico. The increasing prevalence of obesity worldwide is due to changes in environmental factors, including lower physical activity and overeating, but physiological and genetic factors, which may vary among distinct populations, are also involved (Loos and Bouchard, 2003; Wilborn et al., 2005). Epidemiological and genetic studies have revealed the relevance of the leptin/melanocortin pathway to regulate whole body energy homeostasis (Stunkard et al., 1986; Coll et al., 2004; Malis et al., 2005).

The adipocyte-derived hormone leptin interacts with the long isoform of transmembrane Leptin Receptor (LEPR) located in the arcuate nucleus of hypothalamus to activate JAK/STAT and Fat/STAT pathway sand alter expression of hypothalamic neuropeptides (Ghilardi et al., 1996; Woods and Stock, 1996; Auwerx and Stael, 1998; Chen et al., 1996; Fruhbeck, 2006). The anorexic Proopiomelanocortin (POMC) and Cocaine-and Amphetamine-Related Transcript (CART) neurons synthesize the Alpha Melanocyte Stimulating Hormone $(\alpha-\mathrm{MSH})$, which activates MC4R receptor in the paraventricular nucleus, resulting in a satiety signal. Other neurons express the orexigenic Neuro Peptide Y (NPY) and Agouti Related Protein (AGRP), which acts as a potent inhibitor of Melano Cortin 3 Receptor (MC3R) and Melano Cortin 4 Receptor (MC4R) (Clement, 2005; Harrold and Williams, 2006). Despite the fundamental role of leptin in energy balance regulation, only few obese patients present leptin deficiency as a result of rare mutations that cause severe monogenic syndromes (Montague et al., 1997; Strobel et al., 1998; Farooqi and O'Rahilly, 2000). Actually, most obese individuals have increased leptin concentrations in blood (Maffei et al., 1995; Considine et al., 1996; Schwartz et al., 1997), which led to the concept of leptin resistance (Bjorbaek et al., 1999). This phenomenon has been related to genetic mutations (Considine et al., 1995), leptin self-regulation (Scarpace et al., 2001; 2005; Zhang and Scarpace, 2006), limited tissue access due to saturation of leptin transport by LEPR-a (Banks et al., 1996) and cellular or circulating molecular regulation (Cheng et al., 2002). Leptin resistance explains why exogenous administration of this hormone is not efficient to control body weight in the majority of obese patients (Heymsfield et al., 1999).

Lep and lepr genes have been identified in human (Zhang et al., 1994; Tartaglia et al., 1995) and mapped to $7 \mathrm{q} 31.3$ (Green et al., 1995) and 1p31 (Chung et al., 1996) chromosomes, respectively. Many Single-Nucleotide Polymorphisms (SNPs) in lep and lepr genes have been related to obesity in distinct populations. Notably, the G-
2548A polymorphism in lep promoter (Mammes et al., 1998; 2000; Hoffstedt et al., 2002; Wang et al., 2006; Duarte et al., 2007; Hinuy et al., 2008) and the Q223R polymorphism in lepr gene ( $\mathrm{A}>\mathrm{G}$ nucleotide substitution) (Gotoda et al., 1997; Thompson et al., 1997; Chagnon et al., 2000; Quinton et al., 2001; Yiannakouris et al., 2001; Duarte et al., 2007; Fairbrother et al., 2007) have been associated with obesity and high leptin levels in several populations, although no linkage was found in other groups (Norman et al., 1996; Matsuoka et al., 1997; Silver et al., 1997; Wauters et al., 2001; Heo et al., 2002; Mergen et al., 2007), which clearly highlights the relevance of genetic components of obesity in each population. To date, little is known about the association of lep G-2548A (rs7799039) and lepr Q223R (rs1137101) polymorphisms with obesity in the Mexican population. Guizar-Mendoza et al. (2005) reported that there was no difference in genotype frequencies for Q223R polymorphism between obese and normal weight Mexican adolescents. However, Q223R change was associated with body fat percentage and leptin levels in subjects with higher insulin levels, supporting the hypothesis that it could be associated with haemodynamic and metabolic disturbances related to obesity in this population. Here, we evaluated the genetic association of $\mathrm{G}-2548 \mathrm{~A}$ polymorphism in lep gene promoter and Q223R polymorphism in lepr gene, with BMI and leptin level in adult Mexican people. Our results provided evidence that GG genotype in lep gene promoter was significantly associated with high leptin levels and suggested as a protecting factor for obesity in Mexican women.

\section{MATERIALS AND METHODS}

\subsection{Subjects}

The study was approved by the Ethics Committee of the Institution. Participants were recruited at the Acupuncture Clinic of the National School of Medicine and Homeopathy of the National Polytechnic Institute, Mexico City, Mexico. Eligibility criteria included: live in Mexico City or suburbs, be Mexican from at least three generations, agree with blood sample collection and provide written informed consent to participate in the study. A standard health questionnaire, which contained a complete medical history, including current and previous medication, was administered by a physician. Patients with a known illness related to obesity (such as hypothyroidism), cancer, uncontrolled diabetes, hypertension, use of glucocorticoids, insulin, among others, were excluded. Data on gender, age and birth place were also assessed. 


\subsection{Clinical Evaluation and Sample Collection}

Clinical evaluation consisted of weight $(\mathrm{kg})$ and height (m) measurements to determine Body Mass Index (BMI) expressed in $\mathrm{kg} / \mathrm{m}^{2}$, as well as waist and hip circumferences $(\mathrm{cm})$ determination to estimate Waist/Hip $(\mathrm{W} / \mathrm{H})$ index. Fat Mass Percentage (FMP) was calculated using the Hogdon formula (Hodgdon and Beckett, 1984a; 1984b). During the medical interview, two venous blood samples were collected from subjects in fasting state (at least $8 \mathrm{~h}$ overnight) to perform molecular genetics and biochemical analyses. One was centrifuged (3000 rpm for $15 \mathrm{~min}$ ) at $4^{\circ} \mathrm{C}$ to obtain serum for ELISA assays; the other was conserved in EDTA-containing glass tube at $20^{\circ} \mathrm{C}$ to further purify genomic DNA.

\subsection{Genotyping}

Genomic DNA was isolated from EDTAanticoagulated whole peripheral blood samples using the Flexi Gene DNA kit (Qiagen). G-2548A polymorphism in lep gene promoter and Q223R polymorphism at codon 223 in lepr gene coding region were determined by polymerase chain reaction-restriction fragment length polymorphism (PCR-RFLP). Briefly, a 242 bp fragment of lep gene promoter was PCR amplified from genomic DNA (100 ng) using 25 picomols of each specific forward (5'-TTTCCTGTAATTTTCCCGTGAG-3') and reverse (5'-AAAGCAAAGACAGGCATAAA-3') primers. PCR was performed at $94^{\circ} \mathrm{C}$ for $5 \mathrm{~min}, 94^{\circ} \mathrm{C}$ for $60 \mathrm{~s}, 55^{\circ} \mathrm{C}$ for $60 \mathrm{~s}$ and $72^{\circ} \mathrm{C}$ for $60 \mathrm{~s}$, for 30 cycles, with a final extension step at $72^{\circ} \mathrm{C}$ for $5 \mathrm{~min}$ in the presence of Taq DNA polymerase master mix (Ampliqon). PCR products size was confirmed through $2 \%$ agarose gel electrophoresis and ethidium bromide staining. PCR products $(0.5 \mu \mathrm{g}$ DNA) were then treated with $1 \mathrm{U}$ Cfo I (Promega) for $4 \mathrm{~h}$ at $37^{\circ} \mathrm{C}$. Restricted samples were resolved by $10 \%$ polyacrylamide gel electrophoresis and visualized by ethidium bromide staining. Two fragments of 181 and $61 \mathrm{bp}$ were expected for homozygotes GG, three fragments of 242, 181 and $61 \mathrm{bp}$ for heterozygotes GA and a unique $242 \mathrm{bp}$ fragment for homozygotes AA (Stunff et al., 2000). Genotyping of lepr Q223R polymorphism involved PCR amplification of a $421 \mathrm{bp}$ fragment using specific forward (5'ACCCTTTAAGCTGGGTGTCCCAAATAG-3') and reverse (5'AGCTAGCAAATATTTTTGTAAGCAATT$\left.3^{\prime}\right)$ primers , as described above, followed by enzymatic restriction with $1 \mathrm{U} \mathrm{Msp} \mathrm{I} \mathrm{(Promega)} \mathrm{for} 4 \mathrm{~h}$ at $37^{\circ} \mathrm{C}$. After visualization of the generated fragments in ethidium bromide stained polyacrylamide gels, samples showing two fragments of 294 and 127 bp were classified as homozygotes AA, the presence of three fragments of 421, 294 and 127 bp indicated heterozygotes GA, while a single band of $421 \mathrm{bp}$ was found in homozygote GG (Echwald et al., 1997). PCR-RFLP assays were performed in triplicate for each sample. PCR products from five randomly selected samples were automatically sequenced to confirm genotyping.

\subsection{Leptin Assay}

Serum leptin levels were analyzed by ELISA assay using the Human Leptin ELISA kit (Millipore) whose sensitivity was $0.5 \mathrm{ng} \mathrm{mL}{ }^{-1}$. Leptin concentrations were measured in triplicate and calculated from standard curves generated for each assay by using the recombinant human leptin provided in the kit.

\subsection{Statistical Analyses}

Descriptive characteristics of the variables (age, BMI, FMP, W/H index, leptin level) were expressed as the mean \pm Standard Deviation (SD). Age, BMI, FMP and W/H index values in female and male was compared by the $\mathrm{t}$ student test. Allele frequencies were estimated by genocounting method and genotype distribution of both polymorphisms was tested for Hardy-Weinberg Equilibrium (HWE). A chi-square $\left(\chi^{2}\right)$ test was performed across allele frequencies and genotypes distribution for $\mathrm{G}$ 2548A and Q223R polymorphisms to study their association with BMI, FMP and $\mathrm{W} / \mathrm{H}$ index. Binary logistic regressions were performed to test independent variables (gene polymorphism) and body composition variables (BMI, FMP and $\mathrm{W} / \mathrm{H}$ index) used as dependent variables. Odd Ratio (OR) of each polymorphism was also calculated with respect to BMI. ANOVA-TUKEY HSD was used to compare means of leptin level between groups, exclusively considering the values that lie within two standard deviations. The level of significance was defined as $p \leq 0.05$. All statistical analyses were performed using the SPSS 13.0 software package.

\section{RESULTS}

\subsection{Subject's Characteristics}

A total of 160 patients (119 women and 41 men) were recruited at the Acupuncture Clinic of the National School of Medicine and Homeopathy of the National Polytechnic Institute, Mexico City, Mexico and invited to participate in the study. All of them complied with the eligibility criteria, i.e., they were Mexican from at least three generations, live in Mexico City or suburbs, did not present any known illness that may cause obesity, agreed with blood sample collection and signed the informed consent. The population was heavily female, which reflects the sex ratio people attending the Acupuncture 
Clinic. Data analysis showed that $73.1 \%$ subjects were born in Mexico City. Mean age was $36.73 \pm 13.8$ years.

Mean BMI, FMP and W/H index were $29.5 \pm 6.7$ $\mathrm{kg} / \mathrm{m}^{2}, 39.0 \pm 11.3 \%$ and $0.8837 \pm 0.08001$, respectively. There was no significant difference in age, BMI, FMP or $\mathrm{W} / \mathrm{H}$ index between female and male as determined by the t-student test. The 160 patients were clustered according to gender, age and SEEDO (http://www.seedo.es/Obesidadysalud/Consejosdenutrici\% C3\%B3n/tabid/135/Default.aspx\#clasificacion) and WHO(http://apps.who.int/bmi/index.jsp?introPage=intro 3 .html) recommendations to classify obesity grade (Fig. 1). Women and men subpopulations presented a similar age distribution: the main group corresponded to $19-44$ years old $(57.9 \%$ women and $68.3 \%$ men), followed by the $45-$
64 years old group (34.5\% women and $24.4 \%$ men) and the $<18$ years old group ( $7.6 \%$ women and $4.8 \%$ men).

Table 1. Genotype distribution and allele frequencies of lep promoter and lepr gene polymorphisms in the whole study population (160 subjects). Percentage and number of cases (in parentheses) are given for each genotype. Only percentage is given for allele

\begin{tabular}{llll}
\hline & & Lep: G-2548A & Lepr: Q223R \\
\hline Genotypes & $1 / 1$ & $41 \%(66)$ & $24.4 \%(33)$ \\
& $1 / 2$ & $41 \%(66)$ & $55 \%(88)$ \\
\multirow{3}{*}{ Alleles } & $2 / 2$ & $17.5 \%(28)$ & $20.6 \%(39)$ \\
& 1 & $61.90 \%$ & $51.80 \%$ \\
& 2 & $38.10 \%$ & $48.10 \%$ \\
\hline
\end{tabular}

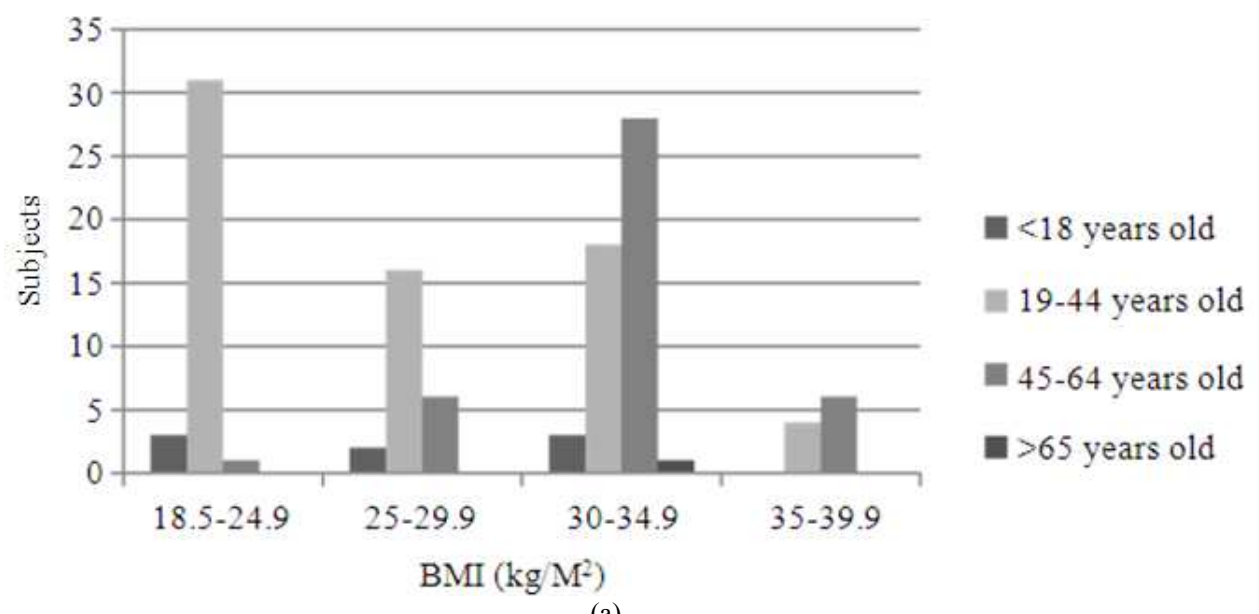

(a)

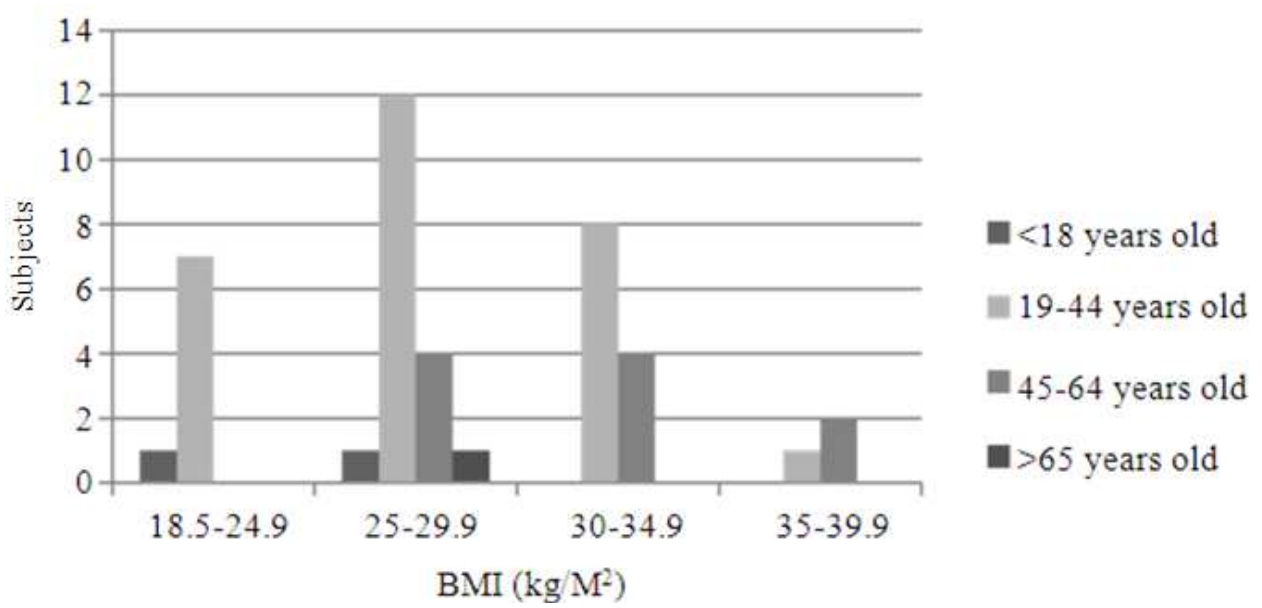

(b)

Fig.1. Characteristics of the study population. The 160 subjects were clustered according to sex, age and BMI. A, women (119 subjects); B, men (41 subjects) 
The $\geq 65$ years old group was the less represented in both populations ( $0.8 \%$ women and $2.4 \%$ men). A subset of 43 people (35 women and 8 men) was considered as normal weight with $18.5 \mathrm{~kg} / \mathrm{m}^{2}<\mathrm{BMI} \leq 24.9 \mathrm{~kg} / \mathrm{m}^{2} ; 117$ subjects (84 women and 33 men) presented BMI $\geq 25 \mathrm{~kg} / \mathrm{m}^{2}$, including overweight subjects (24 women and 18 men with $25 \mathrm{~kg} / \mathrm{m}^{2}<$ BMI $\left.\leq 29.9 \mathrm{~kg} / \mathrm{m}^{2}\right)$, obesity I subjects $(50$ women and 12 men with $30 \mathrm{~kg} / \mathrm{m}^{2}<\mathrm{BMI} \leq 39.9 \mathrm{~kg} / \mathrm{m}^{2}$ ) and obesity II subjects ( 10 women and 3 men with $\mathrm{BMI} \geq 40$ $\mathrm{kg} / \mathrm{m}^{2}$ ). In women, the most represented group corresponded to 45-64 years old individuals with obesity I $(24.3 \%)$, whereas $19-44$ years old overweight individuals predominated in men.

\subsection{Genotype and Allele Frequencies}

Genotyping assays were successful for $100 \%$ of the samples tested and sequencing of five randomly selected PCR products was used as quality control to confirm genotypes. Table 1 shows the distribution of lep G-2548A and leprQ223R polymorphisms in the whole study population. Lep promoter polymorphism distribution exhibited a slight deviation from HWE with the predominance of GG and GA genotypes (in the model $\mathrm{p}^{2}$ $+2 p q+q^{2}$, obtained values were as follows: $p^{2}=0.38$, $2 \mathrm{pq}=0.47$ and $\mathrm{q}^{2}=0.14$ ) probably because of the higher frequency of allele $\mathrm{G}(\mathrm{G}: 61.9 \%)$ in the study population due to its multi-ethnicity. In contrast, lepr genotypes distribution was as expected from the HWE $\left(\mathrm{p}^{2}=0.26\right.$, $2 \mathrm{pq}=0.49$ and $\left.\mathrm{q}^{2}=0.23\right)$. The same observations were made when evaluating independent men and women groups (data not shown).

\subsection{Genotypes, alleles and BMI}

To evaluate whether lepG-2548A and leprQ223R polymorphisms were associated with BMI in the study population, genotypes distribution and alleles frequencies from normal weight $\left(18.5 \mathrm{~kg} / \mathrm{m}^{2}<\mathrm{BMI} \leq 24.9 \mathrm{~kg} / \mathrm{m}^{2}\right)$ and overweight/obese $\left(\mathrm{BMI} \geq 25 \mathrm{~kg} / \mathrm{m}^{2}\right)$ subjects were compared (Table 2). No significant association was found between lep promoter or lepr gene polymorphisms and BMI using the different Mendelian models. To verify the existence of an association between the BMI, FMP and $\mathrm{W} / \mathrm{H}$ index with SNPs, a chi-square test was performed to compare allele and genotype frequencies between normal weight and overweight/obese groups. However, analysis of lepG-2548A polymorphism distribution showed that the dominant model condition appeared to be the most proximal to statistical significance ( $p=0.087$ in $\chi^{2}$ test), suggesting that GA and AA genotypes could be associated with higher BMI in the whole study population. Genotypes distribution and allele's frequencies were also analyzed in relation to other parameters of obesity and results showed that lepG-2548A and leprQ223R polymorphisms were associated with neither FMP nor $\mathrm{W} / \mathrm{H}$ index in the study population.

Table 2. $\chi^{2}$ test results for genotypic and allelic variations in lep promoter and lepr gene between normal weight $\left(18.5<\mathrm{BMI} \leq 24.9 \mathrm{~kg} / \mathrm{m}^{2}\right)$ and overweight/obese $\left(\mathrm{BMI} \geq 25 \mathrm{~kg} / \mathrm{m}^{2}\right)$ subjects of the whole study population. BMI is expressed in $\mathrm{kg} / \mathrm{m}^{2}$. The number

\begin{tabular}{|c|c|c|c|c|c|c|}
\hline \multirow[b]{3}{*}{ Genotypes } & \multicolumn{6}{|c|}{ Polymorphisms } \\
\hline & \multicolumn{3}{|c|}{ Lep: G-2548A } & \multicolumn{3}{|c|}{ Lepr: Q223R } \\
\hline & $\begin{array}{l}18.5<\mathrm{BMI} \\
\leq 24.9\end{array}$ & $\mathrm{BMI} \geq 25$ & $\chi 2 / p$ & $\begin{array}{l}18.5<\mathrm{BMI} \\
\leq 24.9\end{array}$ & $\mathrm{BMI} \geq 25$ & $\chi^{2 / p}$ \\
\hline \multicolumn{7}{|c|}{ Codominant model } \\
\hline $1 / 1$ & 22 & 44 & & 6 & 27 & \\
\hline $1 / 2$ & 15 & 51 & & 27 & 61 & \\
\hline $2 / 2$ & 6 & 22 & $2.40 / 0.301$ & 10 & 29 & $1.948 / 0.378$ \\
\hline \multicolumn{7}{|c|}{ Dominant model } \\
\hline $1 / 1$ & 22 & 44 & & 10 & 29 & \\
\hline $1 / 2+2 / 2$ & 21 & 73 & $2.384 / 0.087$ & 33 & 88 & $0.040 / 0.510$ \\
\hline \multicolumn{7}{|c|}{ Recessive model } \\
\hline $1 / 1+1 / 2$ & 37 & 95 & & 37 & 90 & \\
\hline $2 / 2$ & 6 & 22 & $0.512 / 0.322$ & 6 & 27 & $1.599 / 0.148$ \\
\hline \multicolumn{7}{|l|}{ Alleles } \\
\hline $1(\%)$ & $69 \%$ & $59 \%$ & & $45 \%$ & $49 \%$ & \\
\hline $2(\%)$ & $31 \%$ & $41 \%$ & $2.17 / 0.1407$ & $55 \%$ & $51 \%$ & $0.32 / 0.571$ \\
\hline
\end{tabular}


Because of the low number of men in the study population, genetic analysis was then restricted to the subpopulation of Mexican women. Moreover, data from normal weight and obesity I/II women were compared, without considering overweight individuals; in order to better evidence a possible association between lep G-2548A and leprQ223R polymorphisms and BMI. The dominant model condition was the most proximal model to statistical significance for lep $\mathrm{G}-2548 \mathrm{~A}$ polymorphism $(\mathrm{p}=0.051$ in $\chi^{2}$ test), which suggested that GA and AA genotypes could be associated with higher BMI in Mexican women, whereas GG genotype could be related to normal weight (Table 3). A binary logistic regression test was also performed in order to evaluate the association between lep $\mathrm{G}-2548 \mathrm{~A}$ polymorphism and BMI in terms of Odd Ratio (OR). Data suggested that GG genotype at position2548 in lep gene promoter could have a protective effect in Mexican women in the context of obesity (OR $=0.394$; $95 \% \mathrm{CI}=0.148-1.050, \mathrm{p}=0.062)$. In contrast, no association was found between lepG-2548A polymorphism and $\mathrm{W} / \mathrm{H}$ index nor FMP, which are other important parameters of obesity. Similarly, leprQ223R polymorphism was not associated with BMI, FMP, W/H index nor age in Mexican women.

\subsection{Lep Genotypes, Leptin Level and Obesity in Women}

Since lepG-2548A polymorphism could be affecting lep transcription and therefore leptin synthesis, leptin levels in serum were determined in both women groups (normal weight and obesity I/II) described above, in order to investigate a possible interaction between blood leptin levels, lep promoter polymorphism and BMI in Mexican women. The age factor impact was also evaluated because of hormonal changes that are usually associated with menopause in women. Leptin quantification assays were successful for $100 \%$ of the samples tested. Results showed that mean leptin levels were higher in older women $(61.28+/-5.78$ in $>45$ years old women Vs $35.14+/-4.00$ in $<45$ years old women, suggesting that menopause status could have an effect on leptin production in women. As expected, mean leptin concentration was about 3-fold increased in obese women $\left(60.1 \pm 30.6 \mathrm{ng} \mathrm{mL}^{-1}\right)$ in comparison with normal weight

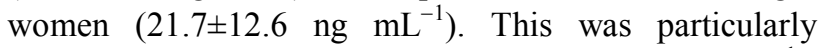
evident in $>45$ years old obese women $\left(61.30 \mathrm{ng} \mathrm{mL}^{-1}\right)$, indicating interactions between age, BMI and leptin level. When comparing each polymorphism in obese and normal weight women, no significant differences were observed in leptin levels. However, leptin concentrations were significantly higher in obese women having the GG variant $\left(63.4 \pm 19.9 \mathrm{ng} \mathrm{mL} \mathrm{mL}^{-1}\right)$ and the GA variant $\left(57.8 \pm 32.2 \mathrm{ng} \mathrm{mL} \mathrm{mL}^{-1}\right)$ in lep promoter in comparison with the AA genotype, with $\mathrm{p}<0.05$ according to ANOVA-TUKEY test (Fig. 2). In contrast, no association was found between BMI, leptin level and lepr gene polymorphism.

Table 3. $\chi^{2}$ test results for genotypic and allelic variations in lep promoter gene between normal weight $\left(18.5<\mathrm{BMI} \leq 24.9 \mathrm{~kg} / \mathrm{m}^{2}\right)$ and obese $\left(\mathrm{BMI} \geq 30 \mathrm{~kg} / \mathrm{m}^{2}\right)$ women. BMI is expressed in $\mathrm{kg} / \mathrm{m}^{2}$.

\begin{tabular}{lccc}
\hline & Lep: G-2548A & & \\
& $-18.5<$ BMI $\leq 24.9$ & BMI $\geq 30$ & $\chi^{2} / \mathrm{p}$ \\
Genotypes & & & \\
\hline Codominant model & & 14.00 & \\
G/G & 14.00 & 22.00 & \\
G/A & 8.00 & 11.00 & $3.66 / 0.162$ \\
A/A & 5.00 & & \\
Dominant model & & 14.00 & \\
G/G & 14.00 & 33.00 & $3.55 / 0.051$ \\
G/A + A/A & 13.00 & & \\
Recessive model & & 38.00 & \\
G/G+G/A & 23.00 & 9.00 & $0.22 / 0.446$ \\
A/A & 4.00 & & \\
Alleles & & $53.20 \%$ & \\
G (\%) & $66.70 \%$ & $46.80 \%$ & $2.558 / .076$ \\
A (\%) & $33.30 \%$ &
\end{tabular}

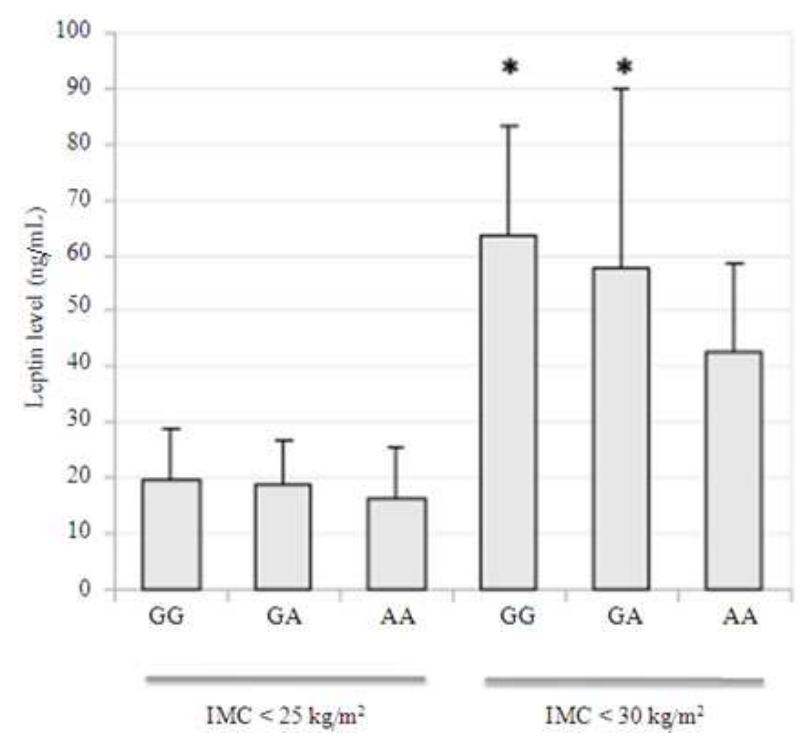

Fig. 2. Effect of G-2548A polymorphism in the leptin promoter and BMI on mean leptin level in obese women. ${ }^{*} p<0.05$ when compared with values of the three genotypes corresponding to IMC $<25 \mathrm{~kg} / \mathrm{m}^{2}$ (ANOVA-TUKET HSD). 


\section{DISCUSSION}

The relevance of distinct genetic polymorphisms for the development of obesity and associated diseases has been studied in the Mexican population (Villalobos-Comparan et al., 2008; Guzman-Guzman et al., 2010; Cruz et al., 2010), but to our knowledge, there is only one published study about lepr Q233R polymorphism and obesity in Mexican Mestizos (Guizar-Mendoza et al., 2005) and none about G$2548 \mathrm{~A}$ change in lep gene promoter.

The non-synonymous Q233R change in leptin receptor is located in the extracellular domain of the protein. This substitution of glutamine for arginine implies an increment in size of amino acid at position 223 and the ability to donate ions that may affect the functional characteristics of leptin receptor, including its affinity for leptin. As a result, the activation of the leptin/melanocortin pathway and regulation of body energy homeostasis could be altered. Here, we showed that Q233R polymorphism is not related to BMI, FMP or W/ H index in Mexican people. This result is in general agreement with previous reports in Mexican adolescents (Guizar-Mendoza et al., 2005), Japanese (Matsuoka et al., 1997), United States Caucasian (Silver et al., 1997), Danese (Echwald et al., 1997), British (Gotoda et al., 1997) and Taiwaneses aborigines (Wang et al., 2006) subjects. In contrast, Q233R polymorphism has been associated with these parameters of obesity in other populations (Thompson et al., 1997; Chagnon et al., 2000; Quinton et al., 2001; Yiannakouris et al., 2001; Duarte et al., 2006; Mattevi et al., 2002). These conflicting data could be due to ethnological factors, as well as the heterogeneity of each study population in age, sex or menopausal and menstrual cycle status.

G-2548A polymorphism in lep gene promoter is closed to a SP-1 DNA binding site (Gong et al., 1996). Hoffstedt et al. (2002) showed that nuclear extracts derived from both U937 cells and human adiposities were able to bind a DNA fragment spanning the-2548G/A polymorphic site. Interestingly, DNA binding affinity was higher when nucleotides A were present at the -2548 position. Then it is possible that lepG-2548A polymorphism could affect lep transcription and therefore leptin synthesis. Although, we did not observe a clear association of lep $\mathrm{G}-2548 \mathrm{~A}$ polymorphism and obesity status, our results suggested that GA and AA genotypes could be associated with higher BMI in Mexican population, whereas GG genotype could be related to lower BMI. It is interesting to note that this association appeared to be more significant in women. In addition, GG genotype seemed to protect women from obesity, whereas it has been associated with a higher risk of being obese (OR: 4.11, CI 95\%: 1.06-15.90, $\mathrm{p}=0.041$ ) in Brazilian women (Hinuy et al., 2008).

Obese Mexican women exhibited increased circulating levels of leptin, which is characteristic of leptin resistance phenotype. This observation that was previously reported in Mexican adolescents (Guizar-Mendoza et al., 2005) and other populations (Maffei et al., 1995; Considine et al., 1996; Schwartz et al., 1997), (12, 42, 43) evidenced that the obesity of the women included in our study was not due to a congenital leptin deficiency. The large standard deviations could be attributed to hormone changes related to the physiological menstrual cycle (45) or the age of the patients. Particularly, the 45-64 years old women had higher leptin levels, independently of their obesity status, which confirmed that the age may have an impact on the secretion of this adipokine. Thus, leptin levels could be synchronous with hormone fluctuations and metabolic needs throughout the menstrual cycle and menopause, promoting an interaction between the hormonal system, food intake, energy expenditure and therefore body weight control (Lecke et al., 2011). Although GG genotype seems to protect women against obesity, leptin levels were not associated to lep G-2548A polymorphism neither in obese women nor in normal weight women, suggesting that this polymorphism does not affect lep transcription. This is not in agreement with a previous study that showed an association between AA genotype and leptin resistance in French Caucasian people evidenced (Mammes et al., 1998).

\section{CONCLUSION}

To our knowledge, this is the first study about the possible relationships between G-2548A polymorphism in lep promoter and Q233R change in leptin receptor with BMI and leptin levels in Mexican people. Taken altogether, our results evidenced that these association depends on ethnological factors and characteristic of each population. Further analysis involving a larger population is required to confirm the biological relevance of G$2548 \mathrm{~A}$ in lep promoter polymorphism for obesity in the Mexican population.

\section{ACKNOWLEDGMENT}

The researchers thank the Mexican patients of the Acupuncture Clinic of ENMH-IPN for their participation in the study and Dr. Flavia Becerril Chavez for her cooperation with clinic patients. This study was supported by Mexican grants from SIP-IPN (20091269, 20090228). 
JPCV and BCV received a fellowship from CONACYT, Mexico. JLO had a fellowship from ICyT-DF, Mexico. CBC, AZC, CARL and LAM received a fellowship from COFAA-IPN, Mexico.

\section{REFERENCES}

Auwerx, J. and B. Staels, 1998. Leptin. Lancet, 351: 737742. DOI: $10.1016 / \mathrm{S} 0140-6736(97) 06348-4$

Banks, W.A., A.J. Kastin, W. Huang, J.B. Jaspan and L.M. Maness, 1996. Leptin enters the brain by a saturable system independent of insulin. Peptides, 17: 305-311. DOI: 10.1016/0196-9781(96)00025-3

Bjorbaek, C., K. El-Haschimi, J.D. Frantz and J.S. Flier, 1999. The role of SOCS-3 in leptin signaling and leptin resistance. J. Biol. Chem., 274: 30059-30065. DOI: $10.1074 / \mathrm{jbc} .274 .42 .30059$

Chagnon, Y.C., J.H. Wilmore, I.B. Borecki, J. Gagnon and L. Perusse et al., 2000. Associations between the leptin receptor gene and adiposity in middle-aged Caucasian males from the HERITAGE family study. J. Clin. Endocrinol. Metab., 85: 29-34. DOI: 10.1210/jc.85.1.29

Chen, H., O. Charlat, L.A. Tartaglia, E.A. Woolf and X. Weng et al., 1996. Evidence that the diabetes gene encodes the leptin receptor: Identification of a mutation in the leptin receptor gene in $\mathrm{db} / \mathrm{db}$ mice. Cell, 84: 491-495. DOI: 10.1016/S00928674(00)81294-5

Cheng, A., N. Uetani, P.D. Simoncic, V.P. Chaubey and A. Lee-Loy et al., 2002. Attenuation of leptin action and regulation of obesity by protein tyrosine phosphatase 1B. Dev. Cell, 2: 497-503. DOI: 10.1016/S1534-5807(02)00149-1

Chung, W.K., L. Power-Kehoe, M. Chua and R.L. Leibel, 1996. Mapping of the OB receptor to $1 p$ in a region of no nconserved gene order from mouse and rat to human. Genome. Res., 6: 431-438. DOI: 10.1101/gr.6.5.431

Clement, K., 2005. Genetics of human obesity. Proc. Nutr. Soc., 64: 133-142. DOI: 10.1079/PNS2005416

Coll, A.P., I.S. Farooqi, B.G. Challis, G.S.H. Yeo and S. O'Rahilly, 2004. Proopiomelanocortin and energy balance: Insights from human and murine genetics. J. Clin. Endocrinol. Metab., 89: 2557-2562. DOI: $10.1210 /$ jc. $2004-0428$

Considine, R.V., E.L. Considine, C.J. Williams, M.R. Nyce and S.A. Magosin et al., 1995. Evidence against either a premature stop codon or the absence of obese gene mRNA in human obesity. J. Clin. Invest., 95: 2986-2988. DOI: 10.1172/JCI118007
Considine, R.V., E.L. Considine, C.J. Williams, T.M. Hyde and J.F. Caro, 1996. The hypothalamic leptin receptor in humans: Identification of incidental sequence polymorphisms and absence of the $\mathrm{db} / \mathrm{db}$ mouse and fa/fa rat mutations. Diabetes, 45: 992-994. DOI: $10.2337 /$ diabetes.45.7.992

Cruz, M., A. Valladares-Salgado, J. Garcia-Mena, K. Ross and M. Edwards et al., 2010. Candidate gene association study conditioning on individual ancestry in patients with type 2 diabetes and metabolic syndrome from Mexico City. Diabetes Metab. Res. Rev., 26: 261-270. DOI: 10.1002/dmrr.1082

Duarte, S.F.P., E.A. Francischetti, V. Genelhu-Abreu, S.G. Barroso and J.U. Braga et al., 2006. p.Q223R leptin receptor polymorphism associated with obesity in Brazilian multiethnic subjects. Am. J. Hum. Biol., 18: 448-453. DOI: 10.1002/ajhb.20519

Duarte, S.F.P., E.A. Francischetti, V.A. Genelhu, P.H. Cabello and M.M. G. Pimentel, 2007. LEPR p.Q223R, $33-A R$ p.W64R and LEP c.-2548G $>$ A gene variants in obese Brazilian subjects. Genet. Mol. Res., 6: 1035-1043.

Echwald, S.M., T.D. Sorensen, T.I.A. Sorensen, A. Tybjaerg-Hansen and T. Andersen et al., 1997. Amino acid variants in the human leptin receptor: Lack of association to juvenile onset obesity. Biochem. Biophys. Res. Commun., 233: 248-252. DOI: $10.1006 /$ bbrc. 1997.6430

Fairbrother, U.L., L.B. Tanko, A.J. Walley, C. Christiansen and P. Froguel et al., 2007. Leptin receptor genotype at Gln223Arg is associated with body composition, BMD and Vertebral Fracture in Postmenopausal Danish Women. J. Bone. Miner. Res., 22: 544-550. DOI: 10.1359/jbmr.070114

Farooqi, I.S. and S. O'Rahilly, 2000. Recent advances in the genetics of severe childhood obesity. Arch. Dis. Child., 83: 31-34. DOI: 10.1136/adc.83.1.31

Fruhbeck, G., 2006. Intracellular signalling pathways activated by leptin. Biochem. J., 393: 7-20. PMID: 16336196

Ghilardi, N., S. Ziegler, A. Wiestner, R. Stoffel and M.H. Heim et al., 1996. Defective STAT signaling by the leptin receptor in diabetic mice. Proc. Natl. Acad. Sci., 93: 6231-6235.

Gong, D.W., S. Bi, R.E. Pratley and B.D. Weintraub, 1996. Genomic structure and promoter analysis of the human obese gene. J. Biol. Chem., 271: 39713974. DOI: $10.1074 /$ jbc.271.8.3971

Gotoda, T., B.S. Manning, A.P. Goldstone, H. Imrie and A.L. Evans et al., 1997. Leptin receptor gene variation and obesity: Lack of association in a white British male population. Hum. Mol. Genet., 6: 869876. DOI: $10.1093 / \mathrm{hmg} / 6.6 .869$ 
Green, E.D., M. Maffei, V.V. Braden, R. Proenca and U. DeSilva et al., 1995. The human Obese (OB) gene: RNA expression pattern and mapping on the physical, cytogenetic and genetic maps of chromosome 7. Genome Res., 5: 5-12. DOI: 10.1101/gr.5.1.5

Guizar-Mendoza, J.M., N. Amador-Licona, S.E. FloresMartinez, M.G. Lopez-Cardona and R. AhuatzinTremary et al., 2005. Association analysis of the Gln223Arg polymorphism in the human leptin receptor gene and traits related to obesity in Mexican adolescents. J. Hum. Hypertens., 19: 341-346. DOI: 10.1038/sj.jhh.1001824

Guzman-Guzman, I.P., J.F. Munoz-Valle, E. Flores-Alfaro, L. Salgado-Goytia and A.B. Salgado-Bernabe et al., 2010. Interleukin- 6 gene promoter polymorphisms and cardiovascular risk factors. A family study. Dis. Markers, 28: 29-36. DOI: 10.3233/DMA-2010-0680

Harrold, J.A. and G. Williams, 2006. Melanocortin-4 receptors, $\beta$-MSH and leptin: Key elements in the satiety pathway. Peptides, 27: 365-371. DOI: 10.1016/j.peptides.2005.01.030

Heo, M., R.L. Leibel, K.R. Fontaine, B.B. Boyer and W.K. Chung et al., 2002. A meta-analytic investigation of linkage and association of common leptin receptor (LEPR) polymorphisms with body mass index and waist circumference. Int. J. Obes. Relat. Metab. Disord. 26: 640-646. DOI: 10.1038/sj/ijo/0801990

Heymsfield, S.B., A.S. Greenberg, K. Fujioka, R.M. Dixon and R. Kushner et al., 1999. Recombinant leptin for weight loss in obese and lean adults: A randomized, controlled, dose-escalation trial. JAMA, 282: 1568-1575. DOI: 10.1001/jama.282.16.1568

Hinuy, H.M., M.H. Hirata, N. Forti, J. Diament and M.F. Sampaio et al., 2008. Leptin G-2548A promoter polymorphism is associated with increased plasma leptin and BMI in Brazilian women. Arq. Bras. Endocrinol. Metabol., 52: 611-616. DOI: 10.1590/S0004-27302008000400006

Hodgdon, J.A. and M.B. Beckett, 1984a. Prediction of percent body fat for U.S. Navy men from body circumferences and height. Report no. 84-11, Naval Health Research Center, San Diego, CA.

Hodgdon, J.A. and M.B. Beckett, 1984b. Prediction of percent body fat for U.S. Navy women from body circumferences and height. Report no. 84-29, Naval Health Research Center, San Diego, CA.

Hoffstedt, J., P. Eriksson, S. Mottagui-Tabar and P. Arner, 2002. A polymorphism in the leptin promoter region (-2548 G/A) influences gene expression and adipose tissue secretion of leptin. Horm. Metab. Res., 34: 355-359. DOI: $10.1055 / \mathrm{s}-2002-33466$
Lecke, S.B., D.M. Morsch and P.M. Spritzer, 2011. Leptin and adiponectin in the female life course. Braz. J. Med. Biol. Res., 44: 381-387. DOI: 10.1590/S0100-879X2011007500035

Loos, R.J.F. and C. Bouchard, 2003. Obesity-is it a genetic disorder? J. Intern. Med., 254: 401-425. DOI: 10.1046/j.1365-2796.2003.01242.x

Maffei, M., J. Halaas, E. Ravussin, R.E. Pratley and G.H. Lee et al., 1995. Leptin levels in human and rodent: measurement of plasma leptin and ob RNA in obese and weight-reduced subjects. Nat. Med., 1: 11551161. DOI: $10.1038 / \mathrm{nm} 1195-1155$

Malis, C., E.L. Rasmussen, P. Poulsen, I. Petersen and K. Christensen et al., 2005. Total and regional fat distribution is strongly influenced by genetic factors in young and elderly twins. Obes. Res., 13: 21392145. DOI: 10.1038/oby.2005.265

Mammes, O., D. Betoulle, R. Aubert, B. Herbeth and G. Siest et al., 2000. Association of the G-2548A polymorphism in the 5 ' region of the LEP gene with overweight. Ann. Hum. Genet., 64: 391-394. DOI: 10.1046/j.1469-1809.2000.6450391.x

Mammes, O., D. Betoulle, R. Aubert, V. Giraud and S. Tuzet et al., 1998. Novel polymorphisms in the 5, region of the LEP gene association with leptin levels and response to low-calorie diet in human obesity. Diabetes, 47: 487-489. DOI: 10.2337/diabetes.47.3.487

Matsuoka, N., Y. Ogawa, K. Hosoda, J. Matsuda and H. Masuzaki et al., 1997. Human leptin receptor gene in obese Japanese subjects: Evidence against either obesity-causing mutations or association of sequence variants with obesity. Diabetologia, 40: 1204-1210. DOI: $10.1007 / \mathrm{s} 001250050808$

Mattevi, V.S., V.M. Zembrzuski and M.H. Hutz, 2002. Association analysis of genes involved in the leptinsignaling pathway with obesity in Brazil. Int. J. Obes. Relat. Metab. Disord., 26: 1179-1185. DOI: 10.1038/sj.ijo.0802067

Mergen, H., C. Karaaslan, M. Mergen, E. DenizOzsoy and M. Ozata, 2007. LEPR, ADBR3, IRS-1 and 5HTT genes polymorphisms do not associate with obesity. Endocr. J., 54: 89-94. PMID: 17124363

Montague, C.T., I.S. Farooqi, J.P. Whitehead, M.A. Soos and H. Rau et al., 1997. Congenital leptin deficiency is associated with severe early-onset obesity in humans. Nature, 387: 903-908. DOI: 10.1038/43185

Norman, R.A., R.L. Leibel, W.K. Chung, L. PowerKehoe and S.C. Chua Jr. et al., 1996. Absence of linkage of obesity and energy metabolism to markers flanking homologues of rodent obesity genes in Pima Indians. Diabetes, 45: 1229-1232. PMID: 8772727 
Quinton, N., A. Lee, R. Ross, R. Eastell and A. Blakemore, 2001. A Single Nucleotide Polymorphism (SNP) in the leptin receptor is associated with BMI, fat mass and leptin levels in postmenopausal Caucasian women. Hum. Genet., 108: 233-236. DOI: 10.1007/s004390100468

Scarpace, P.J., M. Matheny and N. Tumer, 2001. Hypothalamic leptin resistance is associated with impaired leptin signal transduction in aged obese rats. Neuroscience, 104: 1111-1117. DOI: 10.1016/S0306-4522(01)00142-7

Scarpace, P.J., M. Matheny, N. Tumer, K.Y. Cheng and Y. Zhang, 2005. Leptin resistance exacerbates dietinduced obesity and is associated with diminished maximal leptin signalling capacity in rats. Diabetologia, 48: 1075-1083. DOI: 10.1007/s00125005-1763-X

Schwartz, M.W., R.L. Prigeon, S.E. Kahn, M. Nicolson and J. Moore, et al., 1997. Evidence that plasma leptin and insulin levels are associated with body adiposity via different mechanisms. Diabetes Care, 20: 1476-1481. DOI: 10.2337/diacare.20.9.1476

Silver, K., J. Walston, W.K. Chung, F. Yao and V.V. Parikh, et al., 1997. The Gln223Arg and Lys656Asn polymorphisms in the human leptin receptor do not associate with traits related to obesity. Diabetes, 46: 1898-1900.

Strobel, A., T. Issad, L. Camoin, M. Ozata and A.D. Strosberg, 1998. A leptin missense mutation associated with hypogonadism and morbid obesity. Nat. Genet., 18: 213-215. DOI: 10.1038/ng0398-213

Stunff, C.L., C.L. Bihan, N.J. Schork and P. Bougneres, 2000. A common promoter variant of the leptin gene is associated with changes in the relationship between serum leptin and fat mass in obese girls. Diabetes, 49: 2196-2200. DOI: 10.2337/diabetes.49.12.2196

Stunkard, A.J., T.T. Foch and Z. Hrubec, 1986. A twin study of human obesity. JAMA, 256: 51-54. DOI: 10.1001/jama.1986.03380010055024

Tartaglia, L.A., M. Dembski, X. Weng, N. Deng and J. Culpepper et al., 1995. Identification and expression cloning of a leptin receptor, OB-R. Cell, 83: 12631271. DOI: 10.1016/0092-8674(95)90151-5
Thompson, D.B., E. Ravussin, P.H. Bennett and C. Bogardus, 1997. Structure and sequence variation at the human leptin receptor gene in lean and obese Pima Indians. Hum. Mol. Genet., 6: 675-679. DOI: $10.1093 / \mathrm{hmg} / 6.5 .675$

Villalobos-Comparan, M., M.T. Flores-Dorantes, M.T. Villarreal-Molina, M. Rodriguez-Cruz and A.C. Garcia-Ulloa et al., 2008. The FTO gene is associated with adulthood obesity in the Mexican population. Obesity, 16: 2296-2301. DOI: 10.1038/oby.2008.367

Wang, T.N., M.C. Huang, W.T. Chang, A.M.S. Ko and E.M. Tsai et al., 2006. G-2548A polymorphism of the leptin gene is correlated with extreme obesity in Taiwanese aborigines. Obesity, 14: 183-187. DOI: 10.1038/oby.2006.23

Wauters, M., I. Mertens, M. Chagnon, T. Rankinen and R.V. Considine et al., 2001. Polymorphisms in the leptin receptor gene, body composition and fat distribution in overweight and obese women. Int. J. Obes. Relat. Metab. Disord., 25: 714-720.

Wilborn, C., J. Beckham, B. Campbell, T. Harvey and M. Galbreath et al., 2005. Obesity: Prevalence, theories, medical consequences, management and research directions. J. Int. Soc. Sports Nutr., 2: 4-31. DOI: 10.1186/1550-2783-2-2-4

Woods, A.J. and M.J. Stock, 1996. Leptin activation in hypothalamus. Nature, 381: $745 . \quad$ DOI: $10.1038 / 381745 \mathrm{a} 0$

Yiannakouris, N., M. Yannakoulia, L. Melistas, J.L. Chan and D. Klimis-Zacas et al., 2001. The Q223R polymorphism of the leptin receptor gene is significantly associated with obesity and predicts a small percentage of body weight and body composition variability. J. Clin. Endocrinol. Metab., 86: 4434-4439. DOI: 10.1210/jc.86.9.4434

Zhang, Y. and P.J. Scarpace, 2006. The role of leptin in leptin resistance and obesity. Physiol. Behav., 88: 249-256. DOI: 10.1016/j.physbeh.2006.05.038

Zhang, Y., R. Proenca, M. Maffei, M. Barone and L. Leopold, et al., 1994. Positional cloning of the mouse obese gene and its human homologue. Nature, 372: 425-432. DOI: $10.1038 / 372425 \mathrm{a} 0$ 